\title{
Genomic Mutations with Amino Acid Substitutions of Circulating Hepatitis B Virus Found in Non-B, Non-C Patients with Hepatocellular Carcinoma
}

\author{
Nobuhiro NAKamoto, Hidetsugu SaIto, Hirotoshi EbInUmA*, Shinichiro TadA, Yoshimasa SaIto, \\ Satoshi KURITA, Kumi KITAMURA and Hiromasa ISHII
}

\begin{abstract}
Objective Most hepatocellular carcinoma (HCC) in Japan is caused by chronic infection with hepatitis B virus (HBV) or hepatitis C virus (HCV). HBV DNA has been detected in the serum and liver tissue of some proportion of those patients who are HBs antigen-negative and $\mathrm{HCV}$ antibody-negative; i.e., non-B, non-C (NBNC) patients with HCC. We sought to detect HBV DNA in the serum from NBNC HCC cases and to investigate genomic mutations of $\mathrm{HBV}$ in seronegative cases.

Patients and Methods The sera from 26 NBNC HCC patients were examined by polymerase chain reaction (PCR) followed by southern blotting for existence of HBV DNA. The precore/core and polymerase regions of the HBV genome in the sera from five seronegative cases were analyzed by direct sequence.

Results HBV DNA was detected in 17 of 26 patients $(65.4 \%)$. Demographic factors such as age, gender, antiHBs positivity, anti-HBc positivity, complication with cirrhosis, and excessive alcohol intake did not affect circulating HBV positivity. Genomic mutations with amino acid substitutions were detected in the polymerase and the precore regions from one of the five cases, and in the core region from four of the five cases.

Conclusions PCR-based HBV screening is necessary in patients suffering from liver diseases of unknown etiology, although its etiological importance and benefit of viral elimination have not been established. Genomic mutations in the precore/core and the polymerase region detected in this study might be involved in the lack of HBsAg in NBNC HCC cases.
\end{abstract}

(Internal Medicine 42: 322-330, 2003)
Key words: occult hepatitis B virus infection, carcinogenesis, polymerase chain reaction, sequence

\section{Introduction}

In Japan, approximately $90 \%$ of hepatocellular carcinoma (HCC) develops from chronic liver disease caused by chronic infection with hepatitis B virus (HBV) or hepatitis C virus (HCV) (1). There is a group of HCC cases, however, having neither a serum marker of hepatitis $B$ surface antigen (HBsAg) nor that of anti-HCV antibody (HCV-Ab), and this group of patients has been referred to as non- $B$, non- $C$ (NBNC) HCC. Recently, the association of HBV infection in NBNC HCC cases (2-4) as well as chronic hepatitis and cirrhosis without a known etiology has been reported $(5,6)$. Moreover, the frequent detection of HBV DNA in the serum and liver tissue of HBsAg negative but $\mathrm{HCV}-\mathrm{Ab}$ positive HCC patients has been also demonstrated (7). Very low levels of circulating HBV and/or a genomic variety of HBV have been suggested to be the reason why HBV DNA is detected by polymerase chain reaction (PCR) in these cases $(8-12)$.

The HBV genome consists of a 3.2-kb incomplete doublestranded DNA that contains four overlapping open reading frames (ORF); S, X, polymerase and core regions $(13,14)$. The ORF S consists of three regions, pre-S1, pre-S2 and S, encoding for the viral envelope protein ( $\mathrm{HBsAg}$ ). The deletion in the pre-S region (11), and amino acid substitutions and missense mutations in the "a" determinant region might be responsible for antigenic change in the $\operatorname{HBsAg}(15,16)$. The ORF $X$ encodes a transcriptional trans activator, and mutations in the $\mathrm{X}$ region involve replication regulatory ele-

From the Department of Internal Medicine, School of Medicine, Keio University, Tokyo and *the Department of Internal Medicine, Tokyo Electric Power Company Hospital, Tokyo

Received for publication September 3, 2002; Accepted for publication January 10, 2003

Reprint requests should be addressed to Dr. Hiromasa Ishii, the Department of Internal Medicine, School of Medicine, Keio University, 35 Shinanomachi, Shinjuku-ku, Tokyo 160-8582 


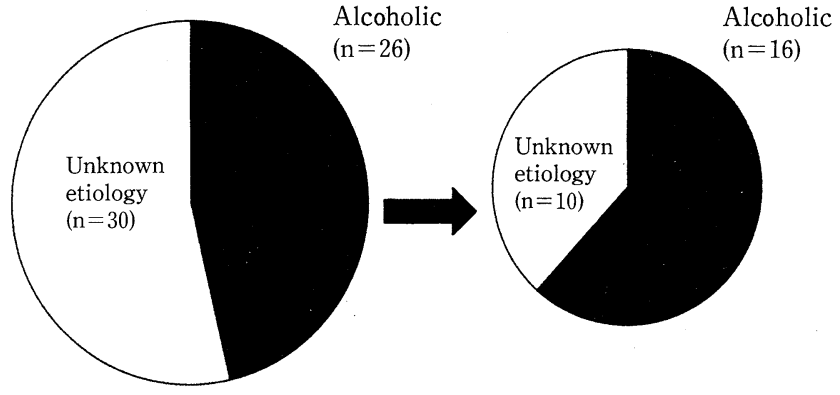

56 NBNC HCC patients
26 NBNC HCC patients whose serum was preserved
Table 1. The Serological and Clinical Profiles of 26 HBsAg(-)/anti-HCV(-) Patients

\begin{tabular}{lc}
\hline \multicolumn{1}{c}{ Characteristic } & No. of patients \\
\hline Gender (male/female) & $21 / 5$ \\
Age & $63.8 \pm 11.6$ \\
Anti-HBs positivity & $7 / 26(26.9 \%)$ \\
Anti-HBc positivity & $8 / 26(30.8 \%)$ \\
HCV RNA positivity & $0 / 26(0 \%)$ \\
Liver cirrhosis & $21 / 26(80.8 \%)$ \\
Excessive alcohol intake & $16 / 26(61.5 \%)$ \\
\hline
\end{tabular}

Figure 1. Proportion of alcoholic patients of non-B, non-C hepatocellular carcinoma.

ments such as core promoter and enhancer (17-19). The ORF P encodes the viral polymerase, and it overlaps with the $S$ region. The "a" determinant of the surface antigen spans the amino acid (aa) 124-147, overlapping the viral polymerase protein from aa 454 to 524 . Thus mutations in the $\mathrm{P}$ gene might affect the antigenicity of the surface antigen. The ORF $\mathrm{C}$ encodes the nucleocapsid protein (hepatitis $\mathrm{B}$ core antigen, $\mathrm{HBcAg}$ ) and hepatitis $\mathrm{B}$ e antigen (HBeAg). It has been considered that mutations in precore/core promoter might cause active hepatitis or fulminant hepatitis (20); however, asymptomatic carriers with these mutations have now been detected in most countries.

The PCR procedure enables detection of the HBV DNA in the serum, liver tissues, and peripheral blood mononuclear cells in HCC patients who are HBsAg negative but anti-HBs or anti-HBc positive, and the HBV DNA has also been detected in rare cases without any serological markers (seronegative) $(2,3,8)$. We performed the specific and sensitive nested PCR and southern blotting of HBV DNA using primers in core and $X$ regions in the sera of patients with NBNC HCC. Our aim was to determine whether or not HBV DNA exists in seronegative $\mathrm{HCC}$ cases, and to investigate genomic mutations of the HBV in such seronegative cases. To address these issues, we attempted to analyze HBV DNA mutations in the pre core/core regions and the polymerase region by direct sequencing.

\section{Patients and Methods}

\section{Patients}

From April 1995 to March 2001, 625 Japanese patients with HCC were admitted to the Division of Gastroenterology and Hepatology at Keio University Hospital and an affiliated hospital. Among them, 56 cases without both serum $\mathrm{HBsAg}$ and HCV-Ab were registered as NBNC HCC. We studied 26 of these 56 patients (male: female $=21: 5$; mean age 63.8 years old) whose sera were stored in good condition ( -80 $\left.{ }^{\circ} \mathrm{C}\right)$. The etiologic considerations of their conditions, such as alcoholism, are shown in Fig. 1. The diagnosis of HCC was made by compilation of ultrasound, computed scanning tomography, angiography and histological findings. Serum samples were collected as soon as $\mathrm{HCC}$ was diagnosed and they were stored at $-80^{\circ} \mathrm{C}$ until use. Among the 26 patients, $21(80.8 \%)$ met the criteria for cirrhosis by biochemical, radiological and histological examinations, $16(61.5 \%)$ had demonstrated excessive alcohol intake (over $65 \mathrm{~g} /$ day intake of ethanol), and 14 (53.8\%) had both cirrhosis and excessive alcohol intake. Most of the patients with both cirrhosis and HCC were introduced from other hospitals, where they had been suspected to have liver masses by radiological examinations. There was no patient diagnosed as HBV carrier in the past among these 21 cirrhosis patients, but there was one patient with a familial history of hepatitis $B$, one with a past history of acute hepatitis (etiology unknown), and 5 with a past history of blood transfusion or acupuncture. The other 14 patients had no particular etiological information. The serological and clinical profiles of these patients are shown in Table 1. Hemochromatosis, Wilson's disease, Budd-Chiari syndrome or $\alpha$-1-antitrypsin deficiency were excluded as etiologic possibilities by biochemical and radiological examinations. As positive controls for $\mathrm{HBV}$ infection, three $\mathrm{HCC}$ patients with $\mathrm{HBsAg}$-positive but $\mathrm{HCV}$-Ab-negative serum were selected, and as negative controls, three HBsAgand HCV-Ab-negative healthy volunteers were studied. Informed consent was taken from all individuals.

\section{Viral serology}

Detection of $\mathrm{HBsAg}$, anti-HBs, anti-HBc, and $\mathrm{HCV}-\mathrm{Ab}$ was performed by enzyme immunoassay, and HCV RNA was detected by reverse transcription-PCR. Results of the anti-HBc assay was expressed by percent inhibition and was defined as positive when the percentage of inhibition detected was $50 \%$ or greater. Of the 26 patients, six were antiHBs (+)/anti HBc (+), one was anti-HBs (+)/anti HBc (-), two were anti-HBs $(-)$ /anti $\mathrm{HBc}(+)$, seventeen were anti$\mathrm{HBs}(-) /$ anti $\mathrm{HBc}(-)$, and none of them were positive for HCV RNA.

\section{DNA extraction from serum}

DNA was extracted from $200 \mu \mathrm{l}$ of serum samples using QIAmp DNA mini-extraction kit (Qiagen K.K., Tokyo, Japan). Briefly, the serum samples were treated with 
Table 2. Sequence and Location of Oligonucleotide Primers Used for Polymerase Chain Reaction (PCR)

\begin{tabular}{lll}
\hline $\begin{array}{l}\text { Core region } \\
\text { 1st PCR }\end{array}$ & sense & 5'-CTGGGAGGAGTTGGGGGA $(1,732-1,750)$ \\
& antisense & 5'-CTAACATTGAGATTCCCCA $(2,454-2,436)$ \\
2nd PCR & sense & 5'-CTGTAGGCATAAATTGGT $(1,783-1,800)$ \\
& antisense & 5'-TCCGGAAGTGTTGATA $(2,336-2,321)$ \\
X region & & \\
& sense & 5'-CTGGATCCTGCGCGGGACGTCCTT $(1,398-1,421)$ \\
& antisense & 5'-GTTCACGGTGGTCTCCAT $(1,625-1,608)$ \\
\hline
\end{tabular}

proteinase $\mathrm{K}$ and then DNA was extracted by phenol/chloroform extraction followed by ethanol precipitation. The extracted DNA was dissolved in $50 \mu \mathrm{l}$ of distilled water.

\section{Polymerase chain reaction coupled with Southern blotting}

Prepared DNA was subjected to PCR amplification and the PCR products were subsequently hybridized with whole HBV DNA by southern blotting, using two pairs of primers specific for the core and $X$ region of the HBV genome (Table 2). The first PCR was carried out to a final volume of $50 \mu \mathrm{l}$ containing $5 \mu \mathrm{l}$ of DNA solution, $50 \mu \mathrm{M}$ each of dNTPs, $1.0 \mu \mathrm{l}$ of each primer, $1 \times$ PCR buffer $(10 \mu \mathrm{M}$ Tris$\mathrm{HCl}, 50 \mu \mathrm{M} \mathrm{KCl}, 1.5 \mu \mathrm{M} \mathrm{MgCl}_{2}$, and $0.001 \%$ gelatin), and 2.5 units of Ampli-Taq polymerase (Perkin-Elmer Cetus, Norwalk, CT). Each amplification was done as follows; 40 cycles consisting of $94^{\circ} \mathrm{C}$ for 1 minute, $56^{\circ} \mathrm{C}$ for 1 minute, and $72^{\circ} \mathrm{C}$ for 1 minute. The second PCR for the core region was performed in the same way as the first using $5 \mu$ of the first PCR products. The amplified PCR products were investigated by staining with ethidium bromide on ultraviolet transilluminator after electrophoresis in $1.5 \%$ agarose gels. To confirm the results, Southern blotting using full-length HBV DNA (VG023, pBRHBadr72, developed by T Yoneyama, which was provided from Health Science Research Resources Bank) was performed. The PCR products were fractionated on $1 \%$ agarose gel and then transferred to a positive-charged nylon membrane according to the standard method of southern blotting. Then, the hybridization was performed with full-length HBV DNA using a random primers labeling and detection kit (Amersham Pharmacia Biotech, Buckinghamshire, UK). Results were considered valid only if the same results were obtained in at least two separate experiments.

\section{Sequence analysis}

Direct sequence was performed for five NBNC HCC cases whose sera showed both $\mathrm{HBsAg}$ and anti-HCVnegative with no serology markers of $\mathrm{HBV}$ infection at all. For direct sequence, each DNA sample was amplified by PCR with 2 sets of primers located in the precore/core and the polymerase region. The primers and amplified regions are summarized in Fig. 2. Briefly, PCR was performed for a total of 40 cycles of $94^{\circ} \mathrm{C}$ for 30 seconds, $52^{\circ} \mathrm{C}$ for 30

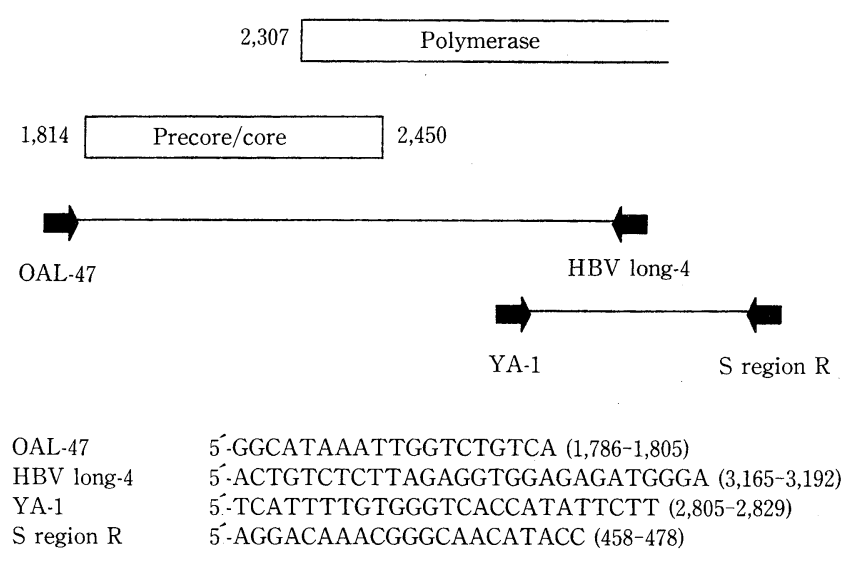

Figure 2. The primers used for polymerase chain reaction and sequencing. After amplification of the regions, polymerase chain reaction products were directly sequenced in both directions.

seconds, and $72^{\circ} \mathrm{C}$ for 2 minutes in a $50 \mu 1$ reaction mixture containing $5 \mu \mathrm{l}$ of DNA solution, $50 \mu \mathrm{M}$ each of dNTPs, 1.0 $\mu \mathrm{l}$ of each primer, $1 \times \mathrm{PCR}$ buffer $(10 \mu \mathrm{M}$ Tris- $\mathrm{HCl}, 50 \mu \mathrm{M}$ $\mathrm{KCl}, 1.5 \mu \mathrm{M} \mathrm{MgCl}_{2}$, and $0.001 \%$ gelatin), and 2.5 units of Ampti-Taq polymerase (Perkin-Elmer Cetus, Norwalk, CT). PCR products were directly sequenced in both directions by an ABI PRISM 377XL DNA Sequencer (Applied Biosystems, Foster City, CA) and homology analysis was performed using affiliated software and FASTA or TFASTA.

\section{Statistical analysis}

All data are expressed as mean \pm S.D. The differences between the mean of two groups were analyzed by the KruskalWallis test. $\mathrm{P}$ values less than 0.05 were considered significant.

\section{Results}

\section{Detection of HBV DNA in serum}

Our test sensitivity was to detect $10^{2}$ copies $/ \mathrm{ml}$ of $\mathrm{HBV}$ DNA. We tried to detect HBV DNA in the serum of patients with NBNC HCC without serum HBsAg and HCV-Ab by one-step or nested PCR followed by southern blotting. To 


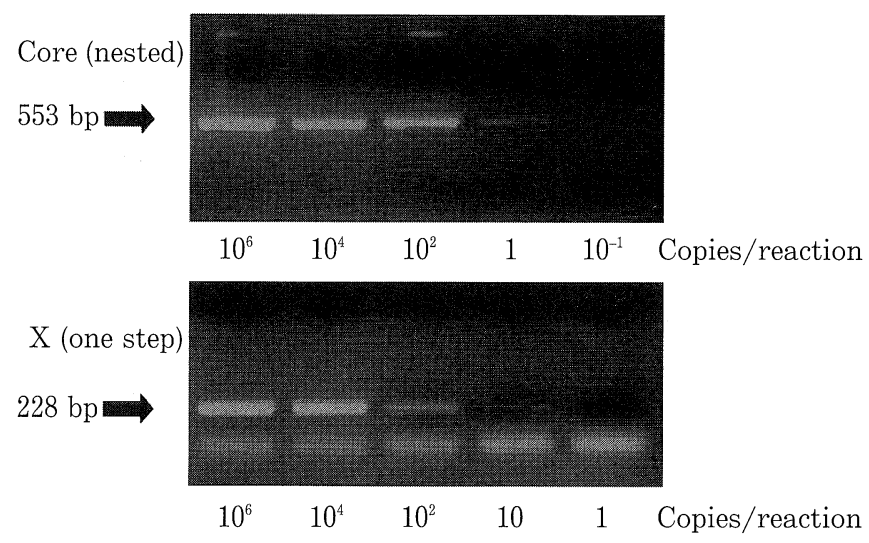

Figure 3. Detection of HBV DNA by nested PCR (core region) and one step PCR (X region). Amplification was performed using $10^{-1}, 1,10,10^{2}, 10^{4}$, and $10^{6}$ copies of HBV DNA.

evaluate the sensitivity of this assay, various copies of HBV DNA (from $10^{-1}$ to $10^{6}$ copies/reaction) were amplified by nested PCR (core region) and one-step PCR (X region). In the core region, HBV DNA was successfully detected using $1 \mathrm{copy} /$ reaction. On the other hand, 10 copies of HBV DNA were detectable in the $X$ region (Fig. 3). Table 3 shows the result of the test and clinical background and serological data of the patients. Using the $\mathrm{X}$ region primers (one-step PCR), HBV DNA was detected in 11 of 26 patients (42.3\%), and with respect to the core region (nested PCR) the positive rate was $17 / 26(65.4 \%)$. HBV DNA was detected in the serum from all of the $\mathrm{HCC}$ patients who are positive for $\mathrm{HBsAg}$ (positive control), while no PCR product was detected from healthy volunteers (negative control). A typical result of PCR detection by ethidium bromide staining and southern blotting is shown in Fig. 4. Correlation to serology markers such as anti-HBs and anti-HBc status was examined. Circulating HBV DNA was positive in four of the six antiHBs (+)/anti-HBc (+) patients, and 11 of the 17 anti-HBs $(-) / a n t i-H B c(-)$ patients (seronegative). There was none in one anti-HBs (+)/anti-HBc (-) patient, but both of the antiHBs (-)/anti-HBc (+) had HBV DNA in the serum. As for the complication of liver cirrhosis, 13 of 21 (61.9\%) patients with cirrhosis had HBV DNA, whereas four of the five (80\%) without cirrhosis had HBV DNA. Two of these four cases were actually biopsied and diagnosed as normal liver histology. As for excessive alcohol intake, 11 of the 16 (68.8\%) alcohol drinkers had HBV DNA, whereas 6 of the 10 (60\%) non-drinkers had HBV DNA.

Table 4 shows the characteristics of the HBV DNApositive group $(n=17)$ and the HBV DNA-negative group $(n=9)$. Demographic factors such as age, sex, serum levels of

Table 3. Serological and Virological Data of the $26 \mathrm{HBsAg}(-) / \mathrm{HCV}-\mathrm{Ab}(-) \mathrm{HCC}$ Patients

\begin{tabular}{|c|c|c|c|c|c|c|c|c|}
\hline No. & Age/Gender & HBs-Ag & Anti-HBs & Anti-HBc & PCR core (nested) & PCR X (one step) & Alcohol* & $\mathrm{LC}^{* *}$ \\
\hline 1 & $30 / \mathrm{F}$ & - & - & - & + & + & - & + \\
\hline 2 & $30 / \mathrm{F}$ & - & - & - & - & + & + & + \\
\hline 3 & $54 / \mathrm{M}$ & - & - & - & + & + & + & + \\
\hline 4 & $57 / \mathrm{M}$ & - & - & - & + & - & + & + \\
\hline 5 & $57 / \mathrm{M}$ & - & - & - & + & - & - & - \\
\hline 6 & $58 / \mathrm{M}$ & - & - & - & + & + & - & + \\
\hline 7 & $61 / \mathrm{M}$ & - & + & + & + & + & + & + \\
\hline 8 & $62 / \mathrm{M}$ & - & - & - & + & + & + & + \\
\hline 9 & $62 / \mathrm{M}$ & - & + & + & - & - & + & + \\
\hline 10 & $63 / \mathrm{M}$ & - & - & - & + & + & + & + \\
\hline 11 & $66 / \mathrm{M}$ & - & - & - & + & + & + & + \\
\hline 12 & $67 / \mathrm{M}$ & - & - & + & + & + & + & + \\
\hline 13 & $67 / \mathrm{M}$ & - & - & - & - & - & + & + \\
\hline 14 & $67 / \mathrm{M}$ & - & - & - & - & - & + & + \\
\hline 15 & $68 / \mathrm{M}$ & - & - & - & + & - & - & - \\
\hline 16 & $68 / \mathrm{M}$ & - & + & + & + & - & + & - \\
\hline 17 & $68 / \mathrm{F}$ & - & + & + & - & - & - & + \\
\hline 18 & $70 / \mathrm{M}$ & - & - & - & + & - & + & + \\
\hline 19 & $70 / \mathrm{M}$ & - & + & + & + & + & + & + \\
\hline 20 & $70 / \mathrm{F}$ & - & - & - & + & + & + & + \\
\hline 21 & $70 / \mathrm{M}$ & - & - & - & - & - & - & + \\
\hline 22 & $71 / \mathrm{M}$ & - & + & + & + & - & - & - \\
\hline 23 & 71/M & - & - & - & - & - & + & - \\
\hline 24 & $76 / \mathrm{F}$ & - & - & + & + & - & - & + \\
\hline 25 & $77 / \mathrm{M}$ & - & + & - & - & - & - & + \\
\hline 26 & $78 / \mathrm{F}$ & - & - & - & - & - & - & + \\
\hline
\end{tabular}

*Alcohol: over $65 \mathrm{~g} /$ day intake of ethanol, $* * \mathrm{LC}$ : liver cirrhosis. 

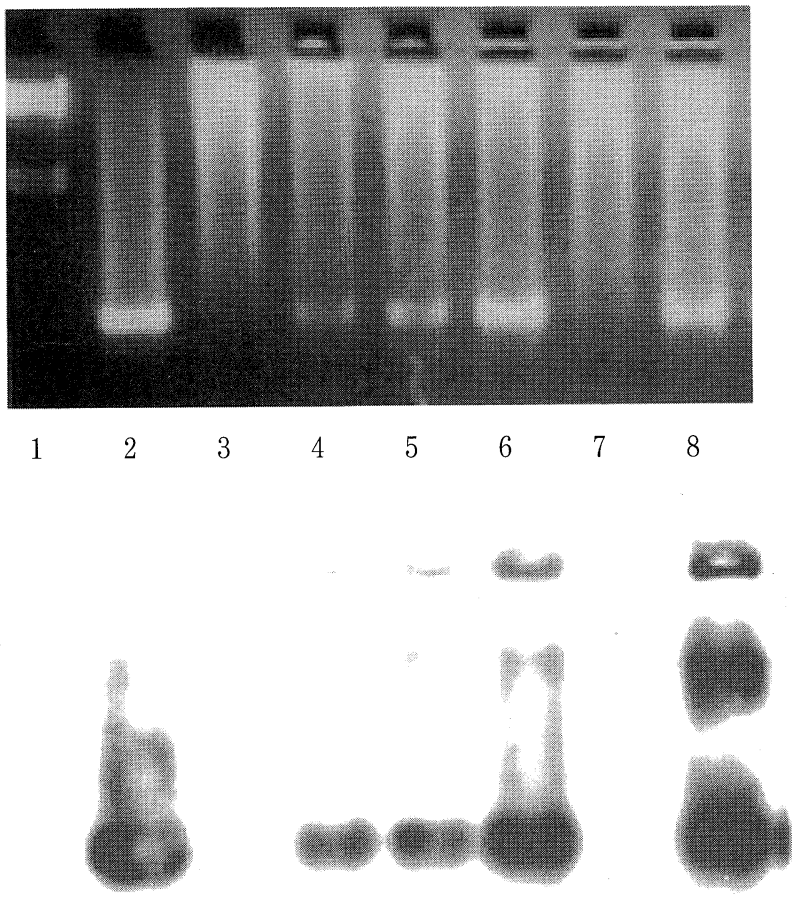

A

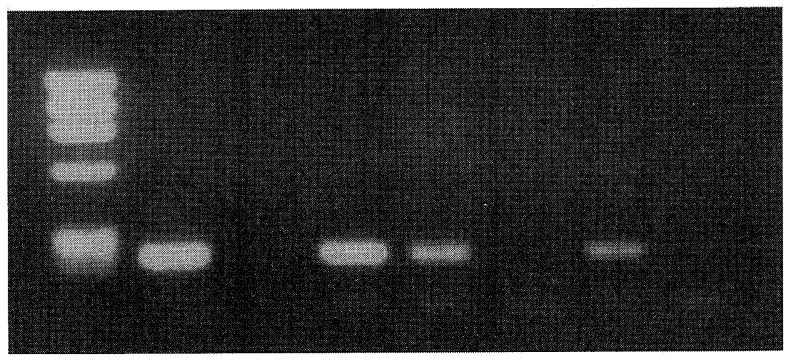

$\begin{array}{lllllll}1 & 2 & 3 & 4 & 5 & 6 & 7\end{array}$

$\mathrm{B}$

Figure 4. Detection of HBV DNA in the serum of patients with non-B, non-C hepatocellular carcinoma by polymerase chain reaction (PCR) followed by southern blot analysis. (A) Nested PCR was performed using primer sets for the core region (upper panel), and the PCR products were confirmed using southern blot hybridization with a full length HBV DNA probe (lower panel). Lane 1, molecular marker ( $\lambda$-HindIII digest); lane 2, positive control; lane 3 , negative control; lane 4, case \# 24; lane 5, case \# 22; lane 6, case \# 20; lane 7, case \# 4; and lane 8, case \# 10. (B) One step PCR using a primer set for the $X$ region. Lane 1, molecular marker ( $\varphi \chi 174$ HaeIII digest); lane 2, positive control; lane 3, negative control; lane 4, case \# 10; lane 5, case \# 1; lane 6, case \# 24; and lane 7, case \# 12 . alanine aminotransferase (ALT) and $\gamma$-glutamyl transpeptidase $(\gamma$-GTP), anti-HBs positivity, anti-HBc positivity, presence of liver cirrhosis, and excessive alcohol intake were not significantly different in the two groups, $\mathrm{HBcAb}$ positivity tended to be higher in the HBV DNA-positive group, though it was not statistically significant.

\section{Sequence analysis}

We determined the nucleotide and amino acid sequences of the precore/core, polymerase, and $\mathrm{preS} / \mathrm{S}$ regions of the five NBNC HCC patients who had HBV DNA but no other HBV serology markers (No. 1, 3, 6, 10, and 11 in Table 3). Each nucleotide region was amplified by PCR, followed by direct sequence. Figure 5 shows the result of nucleotide sequence covering the precore/core and a part of the polymerase region. The PCR products of the five patients were found to be an expected size, indicating there were no major deletions in these regions. One point mutation at nt 1866 (A to C) was detected with the nucleotide sequence in the precore region in patient 1 , which caused an amino acid substitution located at 18 from Gln to Pro. In the core region, a common point mutation was detected at $\mathrm{nt} 2,288$ (from $\mathrm{C}$ to $\mathrm{A}$ ) in patient No. 3, 6, 10, and 11, causing an amino acid substitution located at 130 from Pro to Thr. With regards to the polymerase region, some nucleotide point mutations were discovered and subsequent amino acid substitutions were also detected at aa 168 (Phe to Leu), at 213 (Cys to Ser), and at 214 (Val to Ile). Figure 6 summarizes the amino acid substitution in each region.

\section{Discussion}

Occult HBV infection has recently been identified by sensitive PCR assays in the serum of people who are HBsAg negative. With a typical chronic HBV infection, both HBV DNA and HBsAg should be positive, and the absence of HBsAg indicates the absence of HBV and active viral replication. Occult HBV infection has been documented in a number of patient subgroups of HCC especially those with $\mathrm{HCV}$ infection (7). HBV DNA is present in the serum of up to $52 \%$ (21) of HCV-infected patients who are HBsAg negative and develop HCC. Many of these patients apparently cleared HBV and HBsAg had become negative but they still had demonstrable HBV DNA and proteins in the neoplastic and also in the non-neoplastic liver tissues. In such patients, chronic HCV infection might be a predominant cause of HCC development. On the other hand, in this study, we detected HBV DNA in the sera of Japanese HCC patients with the absence of both the HbsAg as well as the anti-HCV. The result of our study shows that occult HBV infection existed in more than $60 \%$ of these NBNC HCC patients by the sensitive PCR/Southern blotting method. The positive rate of serum HBV DNA detected by nested PCR of core region and by one-step PCR of the $\mathrm{X}$ region was $65.4 \%$ (17/26) and $42.3 \%(11 / 26)$, respectively. This suggests that the positive rates between core and $\mathrm{X}$ regions were different. However, 
Table 4. Comparison Between HBV DNA-positive and HBV DNA-negative Cases $\mathbf{p}<0.05$ were Considered Significant

\begin{tabular}{lccc}
\hline & HBV DNA $(+)$ & HBV DNA $(-)$ & P value \\
\hline Number & 17 & 9 & \\
Age & $62.8 \pm 10.4$ & $65.6 \pm 14.2$ & NS \\
Gender (male/female) & $15 / 2$ & $6 / 3$ & NS \\
Serum ALT* (IU/l) & $42.7 \pm 5.2$ & $38.3 \pm 5.1$ & NS \\
Serum $\gamma$-GTP** (IU $l l)$ & $154.8 \pm 29.0$ & $200.1 \pm 76.8$ & NS \\
Anti-HBs positivity & $4 / 17(24 \%)$ & $3 / 9(33 \%)$ & NS \\
Anti-HBc positivity & $6 / 17(35 \%)$ & $2 / 9(22 \%)$ & NS \\
Liver cirrhosis & $13 / 17(76 \%)$ & $8 / 9(89 \%)$ & NS \\
Excessive alcohol intake & $11 / 17(65 \%)$ & $5 / 9(56 \%)$ & NS \\
\hline
\end{tabular}

*ALT: alanine aminotransferase, $* * \gamma$-GTP: $\gamma$-glutamyl transpeptidase.

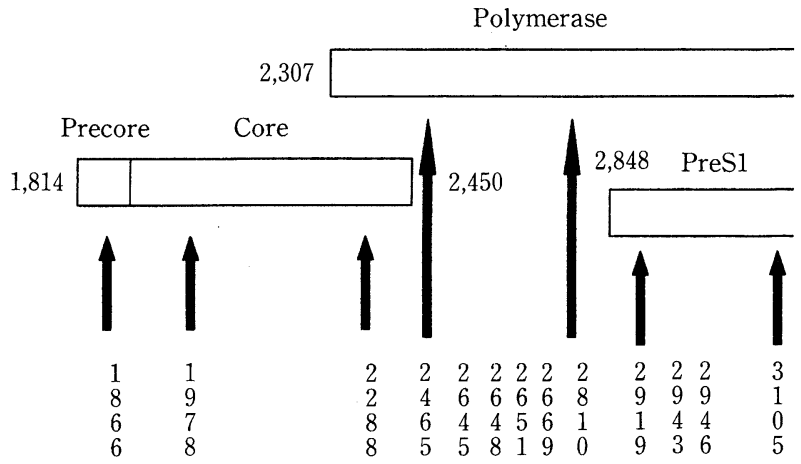

$\begin{array}{llllllll}\text { HBV-DNA } & \text { A } & \text { T } & \text { C } & \text { T T G C A T } & \text { C T G } & \text { A } \\ \text { No. } 1 & \text { C } & \text { C } & - & \text { G C A T G }- & \text { T A A } & \text { T } \\ \text { No. } 2 & - & \text { C } & \text { A G C A T G }- & - & - & - \\ \text { No. } 3 & - & \text { C } & \text { A G C A T G }- & - & - & - \\ \text { No. } 4 & - & \text { C } & \text { A G C A T G A }- & - & - \\ \text { No. } 5 & - & \text { C } & \text { A G C A T G } & - & - & - & - \\ \text { P.C } & - & - & - & - & - & -\end{array}$

Figure 5. The DNA map of mutations in the HBV genome constructed from five $\mathrm{HCC}$ patients with occult $\mathrm{HBV}$ infection without HBV serology markers. Mutations were found in the precore/core, the polymerase and the preS1 regions. The nucleotide sequence of the reported HBV DNA (NC001707) is shown at the top and the numbering begins from the EcoRI site.

only one case was negative by nested PCR of the core region among the 11 cases positive for the $\mathrm{X}$ region, and the other 10 cases were simultaneously positive for the core region. Additional results showed that one-step PCR of the core region showed $38.5 \%(10 / 26)$ positivity, which is similar with that of $\mathrm{X}$ region in this study. These results indicate that the difference in the positivity rate might be due to the differences in sensitivity of PCR between the nested and one-step method. Although the investigated number was small, it is suggested that such an occult HBV infection did not correlate with other HBV serology markers such as anti-HBs and anti-HBc in this study. The patients are broadly classified as being seropositive $(9 / 26,34.6 \%)$ or seronegative $(17 / 26$,

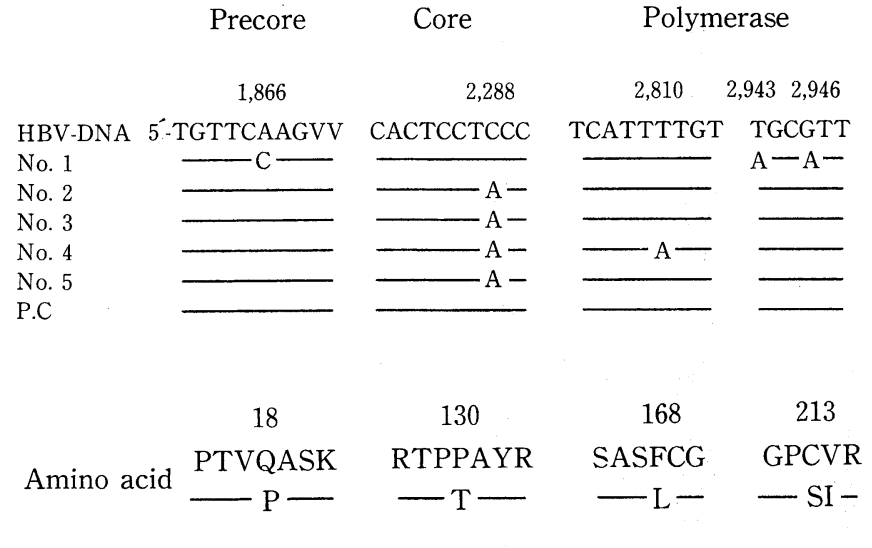

Figure 6. Amino acid substitutions in the precore/core and the polymerase regions of the presumed $\mathrm{HBV}$ protein found in five seronegative patients with non-B, non-C hepatocellular carcinoma with occult $\mathrm{HBV}$ infection. No amino acid substitution was detected in the preS1 region investigated.

65.4\%), and we could detect HBV DNA in 6 of the 9 (66.7\%) seropositive patients and in 11 of the 17 (64.7\%) seronegative patients. Brechot et al indicated in their review that the HBV DNA detection rate is the highest in patients with HCC and chronic hepatitis that are anti-HBc positive/anti-HBs negative, and the HBV DNA detection rate is the lowest in seronegative subjects (8). Thus, our data studying Japanese NBNC HCC patients was quite different. The HBV DNA detection rate in seronegative patients was as high as that in seropositive cases. The same findings were also seen in another study from Japan (2), indicating that some regional difference may be in effect. Recent studies have shown that genotypes of HBV are correlated with the disease severity of chronic HBV infection $(22,23)$. Genotype $C$, which is prevalent in Japanese patients, seems to cause a severe disease progression but genotype $\mathrm{B}$, that is prevalent in other countries, seems to have a mild course. Moreover, genotype B was recently further differentiated to the $\mathrm{Ba}$ and $\mathrm{Bj}$ types, and the $\mathrm{Bj}$ type, which is prevalent in 
Japan, seems to be more damaging (24). Thus, although we have not determined the HBV genotypes in our samples, genotypic differences might be one of the reasons for the difference between the results of studies from Japan and other countries.

Among 16 cases with excessive alcohol intake, HBV DNA was detected in 11 cases (not significant vs. little drinkers). It should be questioned whether or not the alcohol intake is correlated with HCC development in the other 5 cases. Some reports have stated that there is no association between alcohol intake and the risk of liver cancer among the patients with chronic hepatitis $(25,26)$. On the other hand, the opposite opinion has also been reported $(27,28)$. Although it is controversial whether or not alcohol is an independent carcinogen of HCC, alcohol intake is causally involved in the development of liver cirrhosis.

Several possible mechanisms have been hypothesized to explain the lack of the HBsAg in these cases and the true reason is likely to be multifactorial. It has been said that the serum levels of HBV DNA average $10^{2}$ copies $/ \mathrm{ml}$ in individuals with occult $\mathrm{HBV}$ infection (always less than $10^{3}$ copies $/ \mathrm{ml}$ ), and in contrast, those in HBsAg-positive cases are $10^{4}$ to $10^{8}$ copies $/ \mathrm{ml}(8)$. Thus, the main characteristic of occult HBV infection is the very low level of circulating viral DNA and the low copy number of viral DNA in liver samples, consistent with a very low level of viral multiplication. Although the viral levels are extremely low, the presence of complete infectious HBV particles in the individual with seropositive occult HBV infection has been established. One supporting observation is seen in the reinfection of liver grafts after liver transplantation for HBsAg-negative cirrhosis from HBsAg-negative organ donors (29-31). Thus, the absence of HBV markers does not exclude the existence of HBV DNA in serum as a form of infectious HBV particles, and transmission is identical to those in $\mathrm{HBsAg}$-positive sera. One possible explanation of the low level of circulating HBV and low copy number in the liver is that occult HBV infection represents one of a series of clinical stages determined by the host response to the HBV infection. Follow-up of HBV infected patients has revealed that HBV DNA persists in serum after the standard tests have become negative for HBsAg $(12,32)$. It simply reflects a progressive decline in HBV replication. During the course, anti-HBs and anti$\mathrm{HBc}$ always surface, but in rare cases all HBV markers may disappear while HBV DNA persist. The immune system probably contains the HBV infection, limiting viral replication to a minimum. Before the disappearance of all the HBV markers, it might already proceed into the process of hepatocarcinogenesis and liver tumor can appear as NBNC HCC. This scenario is simplest, but immunological mechanisms that maintain the viral load at very low level have not been understood at all. It may be difficult to explain this story solely by immunological mechanisms.

Brechot et al provide the evidence that occult HBV infection exists and that most cases are related to very low levels of $\mathrm{HBV}$ rather than to $\mathrm{HBV}$ mutants that do not express or produce aberrant surface proteins and therefore are undetected by standard testing (8). On the other hand, other data suggest viral factors can be responsible for occult HBV infection. Numerous investigations have been reported interpreting the genetic variability of $\mathrm{HBV}$ in patients with occult HBV infection. First, the mutations in the "a" determinant of $S$ region have been described that could explain the lack of positive serologic assays for HBsAg $(15,16)$. Moreover, because this epitope is the main target for neutralizing antibodies, mutations in this portion may produce "escape variants" from the host immune system (33-35). Mutations in the precore/core region have also been described in HBsAgnegative cases $(12,36)$, and Uchida et al described some precore/core gene variants that may not induce serum HBsAg and anti-HBc in cases of acute or fulminant hepatitis (20). Mutations in X region (8-nt deletion between nt 1,770 and 1,777) and several amino acid substitutions were reported, and Uchida et al postulated their substitutions lead to suppress the replication and expression of HBV DNA by changing $\mathrm{HBx}$ and core promotor function (19). Mutations in the polymerase region have also been described to induce defects in the packaging of pregenomic RNA $(36,37)$. Despite these investigations, the detailed mechanism for the lack of HBsAg has not been clarified. In the present study we detected HBV DNA in the NBNC HCC patients without any serum HBV markers (seronegative), and succeeded in performing the sequence analysis of five patients in the precore/core region and a part of the polymerase region. Several nucleotide point mutations were discovered in the polymerase region (nt $2,465,2,810,2,943$, and 2,946) with amino acid substitutions in the $5^{\prime}$ part (aa 168) and the spacer part (aa 213 and 214). As mentioned above, the 5' part of the polymerase gene encodes a terminal protein serving as a primer for reverse transcription of pregenomic RNA. In this sense, mutations in this position may decrease the replication cycle of HBV DNA, and may cause the failure to detect any HBV markers. In the precore/core region sequence, two nucleotide mutations (nt 1,866 and 2,288) and subsequent amino acid substitutions (aa 18 and 160) were also detected in this study. The point mutation at nt 2,288 (from C to A) was common in four of the five patients, and was not detected in the HBsAg-positive patients, therefore the genetic variability in this region might be the cause of the absence of serology markers.

An important question is whether or not the extremely low level of HBV leads to progressive liver disease, such as cirrhosis or HCC. Data suggest that it does not, although definitive data are lacking. It is not clear if the cirrhosis or $\mathrm{HCC}$ is a result of persistent low levels of HBV or other causes of liver disease, and it remains controversial if occult HBV infection may contribute to the pathogenesis of HCC. The frequency of occult $\mathrm{HBV}$ infection varies in patients with HCC, and the prevalence of HBV DNA varies from 5\% to $80 \%$ (38). Our data showed that it was present in $65 \%$ of the patients with NBNC HCC. This confusion may be due to the lack of well-designed prospective clinical assessment, 
because most of the previous data have been derived from retrospective observation without control groups. Many investigations have implied that, in most patients, intrahepatic HBV DNA may exist in deleted or truncated forms, which may be associated with DNA integration, and the fragmented and integrated DNA was more frequently found in tumors than in non-neoplastic tissue in patients with $\mathrm{HCC}$ with occult HBV infection (39-41). These observations suggest that HBV pregenomic RNA is hardly detectable and inactive $\mathrm{HBV}$ replication may be predominant in patients with NBNC $\mathrm{HCC}$. On the other hand, opposite opinions have been reported that HBV DNA exists in the episomal form with ongoing viral replication, and the integrated HBV DNA does not result in viremia in occult HBV infection (12). Although we cannot declare if HBV DNA exists in the episomal form or the integrated form in hepatocytes, the fact of detection in serum indicates its continuous replication as the episomal form. We must further examine HBV DNA in the tissue sample if available to determine how the viral load is maintained extremely low and how the low copy numbers of HBV associate with the development of HCC.

In summary, HBV DNA was detectable in the serum of patients with NBNC HCC. Although its clinical importance and the viral elimination have not been well documented, PCR-based screening is necessary to detect HBV DNA in patients with chronic liver disease especially when it is progressive and the etiology is unknown. A low level of HBV DNA and a variability of HBV genome may explain the reason why serum detection of HBsAg could fail. We detected several common nucleotide mutations and subsequent amino acid substitutions in the precore/core and the polymerase regions in patients without HBV serological markers, suggesting that these mutations might be involved in the lack of HBsAg. Finally, further studies are needed to clarify the relation between HBV DNA detected in NBNC liver diseases and the development of HCC.

\section{References}

1) Kiyosawa K, Sodayama T, Tanaka E, et al. Interrelationship of blood transfusion, non-A, non-B hepatitis and hepatocellular carcinoma: analysis by detection of antibody to hepatitis $\mathrm{C}$ virus. Hepatology 12: 671-675, 1990.

2) Shiota G, Oyama K, Udagawa A, et al. Occult hepatitis B virus infection in HBs antigen-negative hepatocellular carcinoma in a Japanese population: involvement of $\mathrm{HBx}$ and p53. J Med Virol 62: 151-158, 2000.

3) Yotsuyanagi H, Shintani Y, Moriya K, et al. Virologic analysis of non$\mathrm{B}$, non-C hepatocellular carcinoma in Japan: frequent involvement of hepatitis B virus. J Infect Dis 181: 1920-1928, 2000.

4) Brechot C, Jaffredo F, Lagorce D, et al. Impact of HBV, HCV and GBV-C/ HGV on hepatocellular carcinomas in Europe: results of a Europian concerted action. J Hepatol 29: 173-183, 1998.

5) Chung HT, Lai CL, Lok AS. Pathogenic role of hepatitis B virus in hepatitis B surface antigen-negative decompensated cirrhosis. Hepatology 22: 25-29, 1995.

6) Fukuda R, Ishimura N, Kushiyama $Y$, et al. Hepatitis B virus with $X$ gene mutation is associated with the majority of serologically "silent" non-b, non-c chronic hepatitis. Microbil Immunol 40: 481-488, 1996.
7) Shintani Y, Yotsuyanagi H, Moriya K, et al. The significance of hepatitis $\mathrm{B}$ virus DNA detected in hepatocellular carcinoma of patients with hepatitis C. Cancer 88: 2478-2486, 2000.

8) Brechot C, Thiers V, Kremsdorf D, Nalpas B, Pol S, Paterlini-Brechot P. Persistent hepatitis B virus infection in subjects without hepatitis B surface antigen: clinically significant or purely "occult"? Hepatology 34: 194-203, 2001.

9) Brechot C, Degos F, Lugassy C, et al. Hepatitis B virus DNA in patients with chronic liver disease and negative tests for hepatitis B surface antigen. N Eng J Med 312: 270-276, 1985.

10) Pawlotsky JM, Bastie A, Hezode C, et al. Routine detection and quantification of hepatitis B virus DNA in clinical laboratories: performance of three commercial assays. J Virol Methods 85: 11-21, 2000.

11) Cabrerizo M, Bartolome J, Caramelo C, Barril G, Carreno V. Molecular analysis of hepatitis B virus DNA in serum and peripheral blood mononuclear cells from hepatitis B surface antigen-negative cases. Hepatology 32: 116-123, 2000.

12) Marusawa $H$, Uemoto $S$, Hijikata $M$, et al. Latent hepatitis $B$ virus infection in healthy individuals with antibodies to hepatitis B core antigen. Hepatology 31: 488-495, 2000.

13) Robinson WS, Clayton DA, Greenman RL. DNA of a human hepatitis B virus candidate. J Virol 14: 384-391, 1974.

14) Galibert F, Mandart E, Fitoussi F, Tiollais P, Charnay P. Nucleotide sequence of the hepatitis B virus genome (subtype ayw) cloned in E. Coli. Nature 281: 646-650, 1979.

15) Weinberger KM, Bauer T, Bohm S, Jilg W. High genetic variability of the group-specific a-determinant of hepatitis $\mathrm{B}$ virus surface antigen (HBsAg) and the corresponding fragment of the viral polymerase in chronic virus carriers lacking detectable HBsAg in serum. J Gen Virol 81: 1165-1174, 2000.

16) Carman WF, Van Deursen FJ, Mimms LT, et al. The prevalence of surface antigen variants of hepatitis B virus in Papua New Guinea, South Africa, and Sardinia. Hepatology 26: 1658-1666, 1997.

17) Uchida $T$, Shimojima M, Gotoh $K$, Shikata $T$, Tanaka E, Kiyosawa K. "Silent" hepatitis B virus mutants are responsible for non-A, non-B, non-C, non-D, non-E hepatitis. Microbiol Immunol 38: 281-285, 1994.

18) Poussin K, Dienes H, Sirma H, et al. Expression of mutated hepatitis B virus $\mathrm{X}$ genes in human hepatocellular carcinomas. Int J Cancer 80: 497-505, 1999.

19) Uchida T, Saitoh T, Shinzawa $H$. Mutations of the $X$ region of hepatitis B virus and their clinical implications. Pathol Int 47: 183-193, 1997.

20) Uchida T, Aye TT, Becker SO, et al. Detection of precore/core-mutant hepatitis B virus genome in patients with acute or fulminant hepatitis without serological markers for recent HBV infection. J Hepatol 18: 369-372, 1993.

21) Fukuda R, Ishimura N, Niigaki M, et al. Serologically silent hepatitis $\mathrm{B}$ virus coinfection in patients with hepatitis $\mathrm{C}$ virus-associated chronic liver disease: clinical and virological significance. J Med Virol 58: 201-207, 1999.

22) Orito E, Ichida $T$, Sakugawa $H$, et al. Geographic distribution of hepatitis B virus (HBV) genotype in patients with chronic HBV infection in Japan. Hepatology 34: 590-594, 2001.

23) Kao JH, Chen PJ, Lai MY, Chen DS. Hepatitis B genotypes correlate with clinical outcomes in patients with chronic hepatitis B. Gastroenterology 118: 554-559, 2000.

24) Sugauchi F, Orito E, Ichida T, et al. Hepatitis B virus of genotype B with or without recombination with genotype $\mathrm{C}$ over the precore region plus the core gene. J Virol 76: 5985-5992, 2002.

25) Tsukuma H, Hiyama $T$, Tanaka $S$, et al. Risk factors for hepatocellular carcinoma among patients with chronic liver disease. N Engl J Med 328: 1797-1801, 1993.

26) Hirayama T. A large-scale cohort study on risk factors for primary liver cancer, with special reference to the role of cigarette smoking. Cancer Chemother Pharmacol 23: Supple: S114-117, 1989.

27) Ikeda K, Saitoh S, Koida I, et al. A multivariate analysis of risk factors for hepatocellular carcinogenesis: a prospective observation of 795 patients with viral and alcoholic cirrhosis. Hepatplogy 18: 47-53, 1993. 


\section{NAKAMOTO et al}

28) Tsutsumi M, Ishizaki M, Takada A. Relative risk for the development of hepatocellular carcinoma in alcoholic patients with cirrhosis: a multiple logistic-regression coefficient analysis. Alcohol Clin Exp Res 20: 758-762, 1996.

29) Uemoto $S$, Sugiyama $K$, Marusawa $H$, et al. Transmission of hepatitis $\mathrm{B}$ virus from hepatitis B core antibody-positive donors in living related liver transplants. Transplantation 65: 494-499, 1998.

30) Chazouilleres O, Mamish D, Kim M, et al. "Occult" hepatitis B virus as source of infection in liver transplant recipients. Lancet 343: 142146, 1994.

31) Wachs ME, Amend WJ, Ascher NL, et al. The risk of transmission of hepatitis B from HBsAg (-), HBcAb (+), HB IgM (-) organ donors. Transplantation 59: 230-234, 1995.

32) Yotsuyanagi $\mathrm{H}$, Yasuda $\mathrm{K}$, Iino $\mathrm{S}$, et al. Persistent viremia after recovery from self-limited acute hepatitis B. Hepatology 27: 1377-1382, 1998.

33) Carman $W$, Thomas H, Domingo E. Viral genetic variation: hepatitis-B virus as a clinical example. Lancet 341: 349-353, 1993.

34) Brunetto MR, Rodriguez UA, Bonino F. Hepatitis B virus mutants. Intervirology 42: 69-80, 1999.

35) Yamamoto K, Horikita M, Tsuda F, et al. Naturally occurring escape mutants of hepatitis $B$ virus with various mutations in the $S$ gene in carriers seropositive for antibody to hepatitis B surface antigen. J Virol
68: 2671-2676, 1994.

36) Kremsdorf D, Garreau F, Duclos H, et al. Complete nucleotide sequence and viral envelope protein expression of a hepatitis $\mathrm{B}$ virus DNA derived from a hepatitis B surface antigen-seronegative patient. J Hepatol 18: 244-250, 1993.

37) Blum HE, Galun E, Liang TJ, von Weizsacker F, Wands JR. Naturally occurring missense mutation in the polymerase gene terminating hepatitis B virus replication. J Virol 65: 1836-1842, 1991.

38) $\mathrm{Hu} \mathrm{KQ}$. Occult hepatitis $\mathrm{B}$ virus infection and its clinical implications. J Viral Hepat 9: 243-257, 2002.

39) Paterlini P, Gerken G, Nakajima E, et al. Polymerase chain reaction to detect hepatitis $\mathrm{B}$ virus DNA and RNA sequences in primary liver cancers from patients negative for hepatitis B surface antigen. N Eng J Med 323: 80-85, 1990.

40) Paterlini P, Poussin K, Kew M, Franco D, Brechot C. Selective accumulation of the $X$ transcript of hepatitis $B$ virus in patients negative for hepatitis B surface antigen with hepatocellular carcinoma. Hepatology 21: 313-321, 1995.

41) Takeuchi M, Fujimoto J, Niwamoto H, Yamomoto Y, Okamoto E. Frequent detection of hepatitis B virus X-gene DNA in hepatocellular carcinoma and adjacent liver tissue in hepatitis B surface antigennegative patients. Dig Dis Sci 42: 2264-2269, 1997. 